\title{
Changes in the Cellular Concentrations of Elements in Tobacco Leaf Tissues during Growth and Senescence*
}

\author{
by Patrick Ecblin
}

Pbilip Morris Researcb Center, Ricbmond, Virginia, U.S.A.

and

Department of Botany, University of Cambridge, Cambridge, England

\section{SUMMARY}

Quantitative X-ray microanalysis for nine elements has been carried out on frozen, fully hydrated fracture faces of upper and lower epidermis, palisade and spongy mesophyll cells in leaf tissue of Nicotiana tabacum L. cv. Coker 319 taken from plants at five different stages of growth. Although concentrations of aluminium, silicon and chlorine generally fell below the minimum-detection limit, the values for sodium, magnesium, phosphorus, sulphur, potassium and calcium were consistently higher and showed differences among tissue types and stages of growth. The general trend was for elemental concentrations to increase up to the mature and ripe stages of growth and then to decrease as the leaf ages further. The sodium values were highest at the beginning and end of the five stages of growth, with higher amounts in the epidermal tissues. As the leaves age, the levels of magnesium fell in the photosynthetic tissues but increased in the epidermal tissues. Such changes could be correlated with higher concentrations of potassium at the early stages of growth and with much lower values at the late stages. The sulphur levels showed only small differences between tissue types at all stages of growth. The calcium levels increased with age and there were consistently higher concentrations in the photosynthetic tissues than in the two epidermal layers. The levels of phosphorus were low in all tissue types and decreased with age. There is an increasing positive correlation between phosphorus and magnesium and a decreasing positive correlation

\footnotetext{
Received: 4th March 1988 - accepted: 31st October 1988.
}

between phosphorus and potassium during growth and senescence.

\section{ZUSAMMENFASSUNG}

Vollständig hydratisierte Gewebestücke verschiedener Zellarten (obere und untere Epidermisschicht, Palisaden- und Schwammparenchymzellen) aus der Lamina einer Tabakvarietãt (Nicotiana tabacum L. cv. Coker 319) wurden, nachdem diese den Pflanzen zu fünf verschiedenen Wachstumsstadien entnommen und durch Gefrierbruch aufgeschlossen worden war, mittels Mikroröntgenanalyse quantitativ auf den Gehalt an neun Elementen hin untersucht. Wenngleich die Aluminium-, Silicium- und Chlorkonzentrationen im allgemeinen unter der Nachweisgrenze lagen, waren die Werte für Natrium, Magnesium, Phosphor, Schwefel; Kalium und Calcium durchgehend hōher und zeigten Unterschiede in der Beziehung zu Gewebetyp und Wachstumsstadium. Der Tendenz nach nahm die Konzentration aller Elemente bis zum Ende der $W_{\text {achstumsphase und }}$ der Zeit der Reife zu und verringerten sich, wenn das Blatt alterte. Der Natriumgehalt war zum Beginn und zum Ende der fünf Wachstumsstadien jeweils am höchsten, wobei die Werte im Epidermisgewebe im .Vergleich höher waren. Beim seneszierenden Blatt gingen die Magnesiumwerte im photosynthetischen Gewebe zurück, während sie im Epidermisgewebe zunahmen. Diese Verānderungen waren zum Teil mit den Kaliumkonzentrationen korreliert, die in den ersten Wachstumsstadien höher und in den späteren erheblich niedriger waren. Die Schwefelkonzentration zeigte nur geringe Unterschiede in der Beziehung zu Gewebetyp 
und Wachstumsstadium. Der Calciumgehalt nahm mit zunehmendem Alter des Blattes zu und lag durchgehend im photosynthetischen Gewebe über den Werten, die in den beiden Epidermisschichten gemessen wurden. Die Phosphorwerte waren in allen Gewebetypen niedrig und nahmen mit zunehmendem Alter des Blattes ab. Während des Wachstums und der Phase der Seneszenz verstärkte sich die positive Korrelation zwischen den Phosphor- und Magnesiumwerten, wohingegen jene zwischen den Phosphor- und Kaliumwerten sich verminderte.

\section{RESUME}

En vue de la détermination de leur teneur en neuf élêments chimiques différents, des fragments de tissu foliaire complètement hydratés (épiderme supérieur, épiderme inférieur, tissu palissadique et lacuneux du mésophylle) d'une variéte de tabac (Nicotiana tabacum L. cv. Coker 319) ont été soumis à une microanalyse par rayons $\mathrm{X}$ après avoir été gelés par action de l'azote liquide. Les feuilles avaient été prélevées sur des plantes se trouvant à cinq stades de croissance différents. Bien que les concentrations de l'aluminium, du silicium et du chlore se soient situées généralement en deçà de la limite de détection, les valeurs trouvées pour le sodium, le magnésium, le phosphore, le soufre, le potassium et le calcium se sont avérées constamment plus élevées, tout en variant selon le type du tissu et le stade de croissance considérés. D'une façon générale, la concentration de tous les éléments a tendance à augmenter jusqu'à la fin de la phase de croissance et l'époque de la maturité pour diminuer ensuite au fur et à mesure que la plante vieillit. La teneur en sodium est la plus forte au début et à la fin des cinq stades de croissance, et c'est dans les tissus épidermiques qu'elle est la plus élevée. Dans la feuille sénescente, la teneur en magnésium diminue dans le tissu photosynthétique tandis qu'elle augmente dans les tissus épidermiques. Ces variations ont pu être partiellement mises en corrélation avec la concentration du potassium qui est plus élevée pendant les premiers stades de la croissance pour diminuer par la suite considérablement. La concentration du soufre ne varie que faiblement en fonction du type du tissu et du stade de la croissance. La teneur en calcium augmente avec l'âge de la plante et, dans les tissus photosynthétiques, elle est constamment plus élevée que dans les deux couches épidermiques. La concentration du phosphore est faible dans tous les types de tissu et elle diminue lorsque la plante vieillit.'Pendant la croissance et la phase de sénescence, la corrélation positive entre les teneurs en phosphore et en magnésium s'accuse alors qu'au contraire, elle est moins marquée entre le phosphore et le potassium.

\section{INTRODUCTION}

Inorganic ions play an important role in the growth and development of leaves and, until recently, all the investigations had been carried out either at the level of the whole plant or using whole leaves (1). In addition, these studies had centred either on the physiological effect various elements may have on the whole plant and/ or the growth and form of leaves, or the changes which occur in the plant during senescence. Little or no work had been carried out on changes in the mineral content of maturing leaves and no studies have been made on the distribution of minerals in different tissues of the living leaf as a function of age. It is now quite clear that there are progressive changes in elemental concentration during the development of the vegetative structures of whole plants and this present study was undertaken to investigate these changes at the cellular level in the different tissues of growing and senescing tobacco leaves.

Of the several theories which have been advanced to explain the process of maturation and the causes of senescence in plants, there are two which are most frequently cited. In the first the balance of growth substances is regarded as the potential trigger(s) of the processes. In the second, the biochemical and physiological processes of maturation and senescence are linked closely to the redirection of ions and organic nutrients between leaves of different ages and between other parts of the plant. This present study seeks to follow the cellular basis for these processes.

$\mathrm{X}$-ray microanalysis of single cells from different tissues of frozen, fully hydrated leaves is one of the few ways this type of analysis may be carried out. While lacking the sensitivity of methods which rely either on ion-selective electrodes or fluorescence techniques, $X$-ray analytical methods are sufficiently ( $\pm 5 \%$ ) accurate and permit the in situ analysis of a large number of cells in a reasonably short period of time. Although $\mathrm{X}$-ray microanalysis has already been used to measure the distribution and relative concentration of elements in a number of plant organs, such studies are usually either only qualitative and/or rely on preparative methods in which it is not possible to discount the loss or movement of the element being analysed. However, by combining careful low-temperature specimen preparation with accurate quantitative analytical procedures it has been possible to obtain information about the absolute local concentration of elements in roots $(2,3)$ and leaves $(4,5)$ in both cryosectioned and fractured bulkfrozen hydrated material.

The market quality of many commercially grown plant tissues and organs, fruits, leaves, seeds, flowers etc., depends on selecting and harvesting the product at the right stage of growth. Nowhere is this more important than with tobacco leaves where much effort has already gone into determining the stage of growth at which the leaves should be removed from the plant in order to produce an optimal product. The subjective feel and appearance of the leaf are important criteria, so too are the analyses of the organic constituents. An additional approach would be to relate the mineral content of the leaf tissues to this optional growth stage, both from the point of view of maximalizing flavour and the postharvest processing of the leaf. 


\section{ME'THODS AND MATERIALS}

\section{a. Growth Conditions}

Plants of Nicotiana tabacum L. cv. Coker 319 (Bright tobacco) were grown under natural light in a greenhouse at the Philip Morris Research Center in Richmond from April to September. During this time the temperature ranged from $293 \mathrm{~K}$ to $313 \mathrm{X}$ and the relative humidity from $50 \%$ to $90 \%$. The plants were raised from seed in Jiffy-7 pellets containing vermiculite, peat humus and a small amount of nutrients. The seedlings were transferred after 40 to 50 days to $20 \mathrm{~cm}$ plastic pots containing a 3:1 sterilized mixture of washed sand and vermiculite. Once the plants had been transferred to the larger pots they were given 1.51 of Peters fertilizer solution (Hydro-Sol ${ }^{*}$ : 5/11/26) three times a week. The composition of the fertilizer solution is as follows:

$$
\begin{aligned}
& \mathrm{NO}_{3}^{-}: 2.42 \mathrm{~mol} \mathrm{~m}^{-3}, \\
& \mathrm{PO}_{4}^{3-}: 0.52 \mathrm{~mol} \mathrm{~m}^{-3}, \\
& \mathrm{~K}^{+}: 5.37 \mathrm{~mol} \mathrm{~m}^{-3}, \\
& \mathrm{Mg}^{2+}: 1.23 \mathrm{~mol} \mathrm{~m}^{-3}, \\
& \mathrm{SO}_{4}^{2-}: 1.22 \mathrm{~mol} \mathrm{~m}^{-3}, \\
& \mathrm{Fe}^{2+}: 53.7 \mathrm{mmol} \mathrm{m}^{-3}, \\
& \mathrm{Mn}^{4+}: 9.1 \mathrm{mmol} \mathrm{m}^{-3}, \\
& \mathrm{Zn}^{2+}: 2.29 \mathrm{mmol} \mathrm{m}^{-3}, \\
& \mathrm{Cu}^{2+}: 0.79 \mathrm{mmol} \mathrm{m}^{-3}, \\
& \mathrm{~B}^{4-}: 46.3 \mathrm{mmol} \mathrm{m}^{-3}, \\
& \mathrm{Mo}^{6+}: 1.04 \mathrm{mmol} \mathrm{m}^{-3}, \\
& \mathrm{Cl}^{-}: 1.13 \mathrm{mmol} \mathrm{m}^{-3}, \\
& \mathrm{Na}^{+}: 157 \mathrm{mmol} \mathrm{m} \mathrm{m}^{-3}, \\
& \mathrm{Ca}^{2+}: 311 \mathrm{mmol} \mathrm{m^{-3 }} .
\end{aligned}
$$

Throughout the growing season the plants were adequately watered and showed no signs of turgor loss or water stress. The greenhouse was sprayed once a week with Orthene $e^{*}$, an organophosphorus systemic insecticide against a wide range of insects.

The planting schedule was so arranged to provide sixteen different sets, each of 6 fully grown plants, during July, August and September so that at any one time

\footnotetext{
* Peterr Fertilizer Products, W. R. Grace \& Con, Fogelswille, P, U.S.A.

*t Chevron Chemieal Co., San Francisco, Calif, U.S.A.
}

during the experimental period samples could be taken from at least four different sets of plants. Each set of plants was started at a different time so that at harvesting it was possible to have leaves from any of the five different physiological stages of growth. Leaves were harvested from the mid-stalk position (6th -12 th node counting from the first true bottom leaf), as such leaves are traditionally the basis of the best tobacco filler. The leaves which were picked at five separate stages of development, were different in size, colour and turgidity. Juvenile leaves were approximately one quarter the size of the mature leaves which were fully grown and expanded. Leaves at these two stages were dark green and fully turgid. The ripe leaves which were also turgid were pale green and showed yellowing at the margin of the lamina. Senescent (fully to overmatured) leaves were fully turgid and yellow except for the main vascular tissue which remained pale green. Old (overmatured) leaves were pale yellow or almost white and in some cases were blotched with brown necrotic areas and appeared less turgid in comparison to leaves from the four younger growth stages. Juvenile leaves had developed at the mid-stalk position approximately 10 weeks from seed, mature leaves 13 weeks, ripe leaves 16 to 17 weeks, senescent leaves 20 weeks and old leaves 22 weeks which corresponded to about the time the flowering apices were removed.

\section{b. Sampling Procedures}

A leaf at a given growth stage was excised from the plant early in the day and the petiole immediately placed in a beaker of tap water. Two $10 \mathrm{~mm}^{2}$ samples of leaf tissue were excised from the intervein tissue and placed in a moist-chamber ( $100 \%$ rel. hum.). All samples were taken between the 6th and 7 th vein from the base of the lamina from the right and left hand side of the leaf. Small strips of $1 \mathrm{~mm} \times 3 \mathrm{~mm}$ were cut rapidly using a new razor blade from the excised square of leaf placed on a piece of damp tissue. The strips of leaf tissue were placed in a series of holes in a graphite specimen holder which had previously been partially filled with a wet slurry of a buffered graphite suspension. The samples were quickly quench frozen in turbulent liquid nitrogen within less than a minute of being excised from the tissue and within 5 min of being removed from the plant. This procedure provided fully frozen, hydrated strips of leaf tissue which protruded $1 \mathrm{~mm}$ to $2 \mathrm{~mm}$ above the surface of the carbon specimen stub and held in mechanical and conductive contact by means of the now frozen graphite slurry. The frozen samples were either transferred under liquid nitrogen to the pre-cooled Biochamber for further processing, or stored in a liquid nitrogen-filled Dewar flask.

The low-temperature work was carried out using a Biochamber attached to the side of the microscope column and a Joule-Thompson refrigerator on the specimen stage: The Biochamber is a low-temperature (approx. 
$100 \mathrm{~K}$ ), high-vacuum (approx. $5 \mu \mathrm{Pa}$ ) preparatory device which allows frozen-hydrated samples to be fractured and coated at $110 \mathrm{~K}$ in the absence of melting, sublimation and contamination (6). Specimens are introduced into the Biochamber via an air lock, and are passed to the microscope column via a second air lock, thus maintaining the specimen in a fully frozen-hydrated and uncontaminated state. The Joule-Thompson refrigerator depends on adiabatic cooling using highpressure nitrogen gas. The thin, flexible gas lines allow the stage to be rotated and tilted as well as moving in the $x, y$ and $z$ direction. This flexibility of movement has proved most important in the analysis of highly sculptured fracture surfaces. The samples were fractured in the Biochamber and the fracture faces coated with a thin layer of evaporated chromium. The rationale for using chromium as a coating material is given in an earlier publication (5). The low melting point of this metal and its good conductive properties prevents sample-surface etching and the $K$ and $L X$-ray lines of chromium do not interfere with the elements of interest.

\section{c. Microscopy and Microanalysis}

The microscopy and analysis were carried out using an AMRAY 1600 scanning electron microscope fitted with a turbomolecular pumping system to ensure low contamination and a lanthanum-hexaboride emitter to ensure beam stability. The instrument was modified to electrically isolate the whole of the final aperture assembly, to allow it to be used to measure a calculated portion of the beam current. The calibrated output from the floating aperture is amplified and shown on a digital display and allows the beam current at the level of the specimen to be continually monitored throughout examination and analysis.

The X-ray microanalysis was performed using a Link Systems 860 (Series II) energy-dispersive spectrometer, at a $45^{\circ}$ take-off angle, and spectra were collected for $200 \mathrm{~s}$ at $15 \mathrm{keV}$ and $1 \mathrm{nA}$ which gave between 300 to $500 \mathrm{cps}$ above the strobed zero peak of approximately $600 \mathrm{cps}$ as seen on the computer VDU. The quantitation was carried out using the Link ZAFPB program, which is specially designed for optically rough specimens and bulk biological material $(7,8)$. A recent paper (9) on the influence of surface topography on X-ray intensity confirms that the peak to local background ratio method is the preferred analytical method for samples in which surface roughness cannot be avoided.

Flat, frozen-hydrated fractures of epidermal, palisade and spongy mesophyll cells were analysed for $\mathrm{Na}, \mathrm{Mg}$, $\mathrm{Si}, \mathrm{Al}, \mathrm{P}, \mathrm{S}, \mathrm{Cl}, \mathrm{K}, \mathrm{Ca}$ and $\mathrm{Cr}$ with a reduced raster approximately $10 \mu \mathrm{m}^{2}$ in size and at a magnification of $\times 1000$. No beam damage was observed on the samples other than an occasional distortion of the extremely thin wall of unfractured palisade cells. Analysis was carried out on the central regions of fractured cells avoiding the cell walls. The spatial resolution of the an- alytical system is no better than approx, $5 \mu \mathrm{m}$ and the results which have been obtained are primarily representative of the vacuolar contents of the cell. The concentration of chromium was measured simply to provide the basis of a correction factor for the absorption of soft X-ray by the coating layer. These correction procedures are described in an earlier paper (5).

Measurements were taken from 20 different leaves at each of the five stages of growth and three to four measurements taken from different cells of each of the four cell types, giving approximately 1300 analyses. A total of 46 different plants from 15 different sets of plants have been analysed. Data from replicates of cell types within the same leaf were averaged to reduce the cell to cell variations.

\section{d. Quantitation}

Quantitative X-ray microanalysis of frozen, hydrated plant material is dependent on a number of factors. The problems of beam attenuation and absorption of soft $\mathrm{X}$-rays by conductive coating layers, and irregular specimen geometry have been discussed in an earlier paper (5). In order to calculate the correct elemental concentrations, the specimen should, if possible, remain fully hydrated throughout analysis. It is impossible to judge the degree of hydration of a sample by examining the secondary-electron image (10). Fully hydrated samples have a characteristic high background at the low-energy end of the $\mathrm{X}$-ray spectrum which is missing in dried or even partially dried samples (11). Each X-ray spectrum was visually checked to make sure that data had been obtained from fully hydrated samples. The effect of drying causes a three to fivefold increase in the local concentration of dissolved elements.

Quantitation may be achieved by using the peak to local background ratio method either in comparison with known standards or by making the necessary corrections for the composition of the organic and aqueous matrix of those elements which cannot be measured by the X-ray spectrometer. Peripheral hydrated standards have proved impracticable and imprecise with leaf tissue. Pure-element and known elemental-composition standards are inaccurate when applied directly to organic material. Accurate quantitation has been achieved using the ZAFPB quantitative programme in combination with an independent chemical analysis of leaf-lamina tissue at the ripe stage of growth; measurement of the sample water content and the preparation of pureelement peak profiles from standards of known composition.

Mid-stalk ripe tobacco leaves were dried overnight at $333 \mathrm{~K}$ and the lamina carefully separated from the main veins. The lamina was crushed to small pieces, dried at $373 \mathrm{~K}$ for $3 \mathrm{~h}$ and ground to a fine powder in a ball mill. An elemental analysis, using standard chemical analytical procedures, including autoanalysis ( $\mathrm{CHON}$ ) and electrothermal atomic-absorption spectroscopy $(\mathrm{Na}$ to 
Table 1.

Rolative mass fractions of four elements in fresh and dried ripe tobacco leaves (ash = elements measured by $X$-ray microanalysis). The data for the dried lamina are calculated on a dry-weight basis. The data for the fresh lamina are based on the dry-weight measurements corrected for the average water content of fresh leaves measured at the ripe stage of growth.

\begin{tabular}{lc|c|c|c|c}
\cline { 2 - 6 } & Carbon & Hydrogen & Oxygen & Nitrogen & Ash \\
\hline $\begin{array}{l}\text { Lamina, } \\
\text { dried }\end{array}$ & 0.4476 & 0.0633 & 0.4600 & 0.0080 & 0.0211 \\
$\begin{array}{l}\text { Lamina, } \\
\text { fresh }\end{array}$ & 0.0537 & 0.1020 & 0.8219 & 0.0012 & 0.0212 \\
\hline
\end{tabular}

Ca) (12), was carried out independently at the Philip Morris Research Center, Richmond, Virginia, and at Galbraith Laboratories, Knoxville, Tennessee. Samples for $\mathrm{C}, \mathrm{H}, \mathrm{O}$, and $\mathrm{N}$ measurements were dried again at $333 \mathrm{~K}$ and handled in a dry box containing nitrogen gas before analysis. Throughout the growing season, dryweight measurements were made repeatedly on fresh tobacco leaves at each of the five stages of growth under investigation. The water content of the leaves at the different growth stages was calculated to be: Juvenile $83.4 \%$, Mature $77.0 \%$, Ripe $73.1 \%$, Senescent $79.0 \%$, and Old $85.4 \%$. These measurements were used in combination with the chemical analysis of the dried tissue, to calculate the relative mass fractions of $\mathrm{C}, \mathrm{H}, \mathrm{O}$, and $\mathrm{N}$ in frozen, hydrated tissue. The results are shown in Table 1.

In addition to using these figures for the analysis of the ripe stage of growth, the fresh ripe-lamina matrix was tested against samples from each growth stage adjusted for its water content. The results of these analyses only differed by $4 \%$ and the matrix for the dried ripe lamina was used to calculate the fresh matrix for each of the five different stages of growth. The matrix corrections proved to be correct because the values obtained by $\mathrm{X}$-ray microanalysis for inorganic elements in frozen, hydrated samples are close to the values obtained by chemical analysis.

\section{RESULTS}

It is appropriate to first examine the mean concentration of the nine elements in the leaves irrespective of tissue type or stage of growth (Table 2) and to show that the X-ray analytical results which are giving data at the individual-cell level, bear some relationship to the results obtained by wet-chemical methods at the whole-leaf level (Table 3). When considering these results it must be remembered that some of the values are at or below the minimum-detection limit of the $\mathrm{X}$-ray analytical system. A value of $10 \mathrm{~mol} \mathrm{~m}{ }^{-3}$ fresh weight is considered to be a realistic minimum-detection limit for light elements ( $\mathrm{Na}$ to $\mathrm{P}$ ) but is a conservative esti-
Table 2.

The mean concentration of each of the nine elements in the leaves as measured by low-temperature $X$-ray microanalysis. These values were obtained by combining all the values for each element from all five stages of growth and from all four tissue types. Values are given as $\mathrm{mol} \mathrm{m}^{-3}$ fresh weight $(n-265)$.

\begin{tabular}{c|c}
\hline Element & $\begin{array}{c}\text { Mean concentration } \\
\left(\text { (ol m }^{-3}\right)\end{array}$ \\
\hline $\mathrm{Na}$ & 19 \\
$\mathrm{Mg}$ & 35 \\
$\mathrm{Al}$ & 14 \\
$\mathrm{SI}$ & 9 \\
$\mathrm{P}$ & 12 \\
$\mathrm{~S}$ & 6 \\
$\mathrm{Cl}$ & 7 \\
$\mathrm{~K}$ & 105 \\
$\mathrm{Ca}$ & 16 \\
\hline
\end{tabular}

mate for the higher atomic-number elements ( $\mathrm{S}$ to $\mathrm{Ca}$ ). Table 4 reveals a strong positive correlation between $\mathrm{P}$ $\& \mathrm{Mg}, \mathrm{P} \& \mathrm{~K}$ and $\mathrm{K} \& \mathrm{Cl}$. A less positive correlation exists between $\mathrm{S} \& \mathrm{Na}, \mathrm{S} \& \mathrm{Mg}, \mathrm{Mg} \& \mathrm{Cl}, \mathrm{K} \& \mathrm{Mg}, \mathrm{S}$ $\& \mathrm{P}, \mathrm{P} \& \mathrm{Cl}, \mathrm{K} \& \mathrm{~S}$ and $\mathrm{Ca} \& \mathrm{~S}$. The data relating to $\mathrm{Si}, \mathrm{Al}$ and $\mathrm{Cl}$ are probably of no biological significance because of the demonstrably low levels of these two elements in tobacco leaves.

With two exceptions, thete is a close agreement between the measurements in the two sets of results which shows that $\mathrm{X}$-ray microanalysis of frozen, hydrated fracture faces of bulk samples is a valid and reasonably accurate analytical procedure. The exceptions to this close fit are aluminium and calcium. The higher $\mathrm{X}$-ray figure for aluminium is considered to be due to excessive electron backscatter from the sample coupled with electron backscatter from the outer aluminium

Table 3.

Comparative chemlcal and $X$-ray mlcroanalytical analysis of the concentration of each of the nine elements, expreseed as the mean of the combined values from the four tissue types of leaves, at the rlpe stage of growth. Values given as $\mathrm{mol} \mathrm{m}^{-3}$ fresh weight.

\begin{tabular}{c|c|c}
\hline Element & X-ray analysis & Chemical analysis \\
\hline $\mathrm{Na}$ & 10 & 9 \\
$\mathrm{Mg}$ & 40 & 39 \\
$\mathrm{Al}$ & 14 & 3 \\
$\mathrm{Si}$ & 8 & 6 \\
$\mathrm{P}$ & 10 & 8 \\
$\mathrm{~S}$ & 6 & 8 \\
$\mathrm{Cl}$ & 7 & 8 \\
$\mathrm{~K}$ & 107 & 96 \\
$\mathrm{Ca}$ & 15 & 36 \\
\hline
\end{tabular}


Figure 1.

Combined elemental concentrations in cells from the four tlasue types of the lamina of Nicotiana tabacum as a function of the stage of growth. Values are given as mol $\mathrm{m}^{-3}$ fresh weight ( \pm standard error of the mean). The arrows $(\rightarrow)$ on the vertical axis denote the generally considered average minimumdetection limit for the element concerned; the asterisk $(*)$ is the independently calculated value for the element at the ripe stage of growth as measured by chemical analysis.
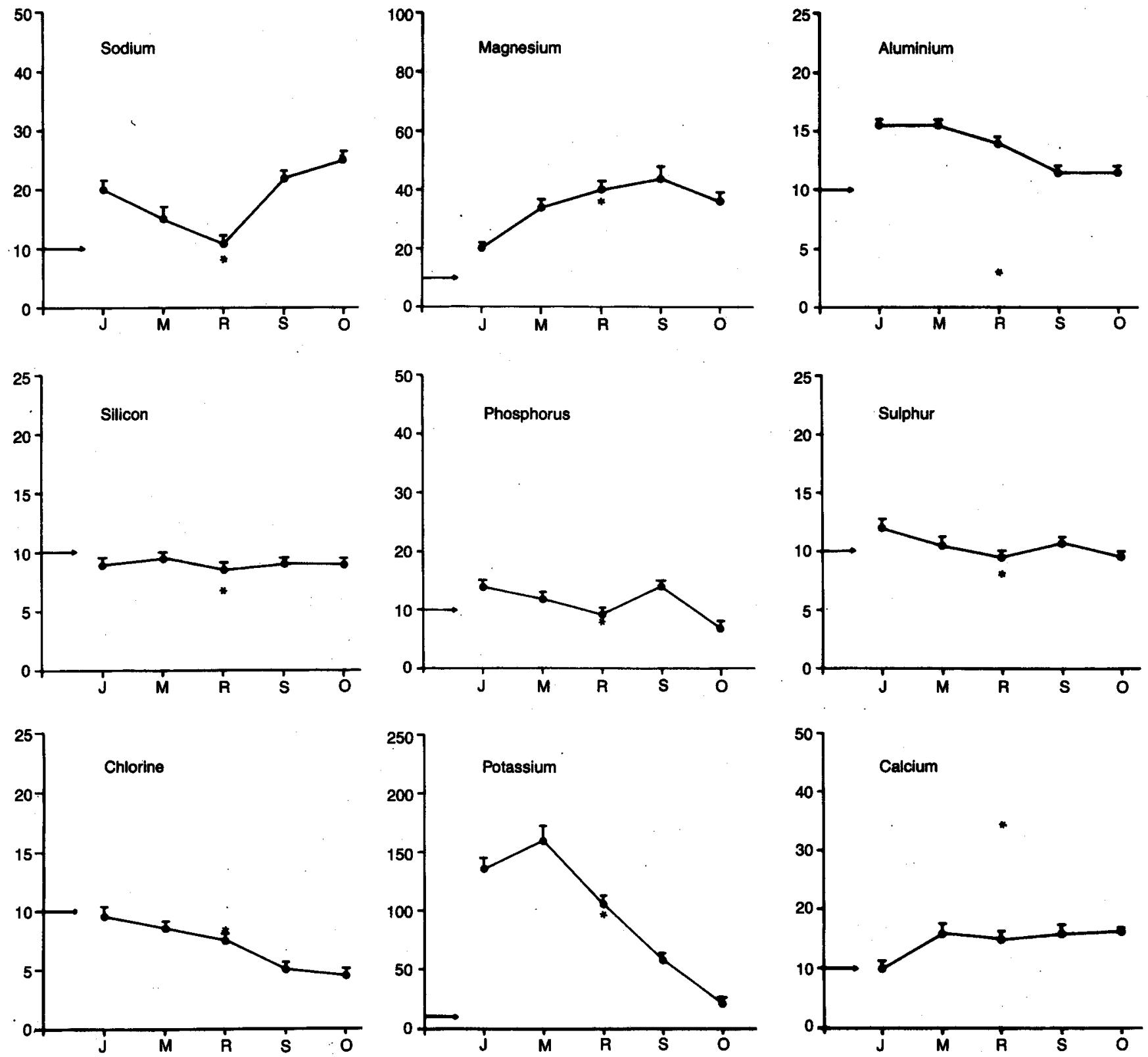

\footnotetext{
$J:$ Juvenile $(n-260)$,

$M$ : Mature ( $n=267$ ),

$R$ : Ripe (n - 255),

S : Senescent ( $n=249$ ),

0 : Old $(n=255)$.
} 
Table 4.

Correlation-coefficlent matrlx of the mean values for each of the nine elements as measured by low-temperature $X$-ray microanalysis. The mean values were obtained by combining all the values for each element from all five stages of growth and from all four tissue types.

\begin{tabular}{c|c|c|c|c|c|c|c|c}
\hline Element & $\mathrm{Na}$ & $\mathrm{Mg}$ & $\mathrm{Al}$ & $\mathrm{Si}$ & $\mathrm{P}$ & $\mathrm{S}$ & $\mathrm{Cl}$ & $\mathrm{K}$ \\
\hline $\mathrm{Mg}$ & 0.0969 & & & & & & & \\
$\mathrm{Al}$ & 0.0745 & 0.0821 & & & & & & \\
$\mathrm{Si}$ & 0.0564 & 0.1533 & $0.3083^{*}$ & & & & & \\
$\mathrm{P}$ & 0.0667 & $0.4241^{*}$ & 0.0118 & 0.0861 & & & & \\
$\mathrm{~S}$ & $0.2492^{*}$ & $0.2345^{*}$ & 0.0889 & 0.0651 & $0.3908^{*}$ & & & \\
$\mathrm{Cl}$ & 0.0904 & $0.2341^{*}$ & 0.1040 & 1.1493 & $0.2751^{*}$ & 0.1616 & & \\
$\mathrm{~K}$ & 0.0426 & $0.0221^{*}$ & 0.0838 & 0.0938 & $0.5891^{*}$ & $0.2875^{*}$ & $0.4685^{*}$ & \\
$\mathrm{Ca}$ & 0.0115 & 0.0323 & 0.0116 & 0.0754 & 0.0042 & $0.2892^{*}$ & 0.0265 & 0.1059 \\
\hline
\end{tabular}

- The $99 \%$ significance levet when degrees of freedom - 250.

edge of the sample holder. An analysis of the sample holder alone showed that this was not the case. However, the presence of fractured leaf samples which protruded above the flat graphite sample holder could have caused additional backscattering and, in turn, spurious aluminium $X$-ray photons. In any event, the figures for aluminium obtained by $\mathrm{X}$-ray microanalysis are close to the minimum-detection limit.

The disparity between the two values for calcium is more readily explained. It is well known that calciumoxalate crystals form in ripening tobacco leaves, and this is reflected in the chemical analysis of the wholelamina tissue. During X-ray microanalysis of individual cells, care was taken to avoid analysing cells which contained obvious calcium-oxalate crystals as this was considered to give biased and unrepresentative results. Hence the disparity between the X-ray and chemical analyses of calcium in ripe tobacco leaves.

The wide fluctuations in the concentration of elements in different tissues at different stages of growth has prompted sorting the data in different ways in order to more closely identify whether the differences in elemental concentration are a function of variation in tissue type, age of tissue or both.

The first of such data sorting is shown in Fig. 1 where the combined elemental concentrations for all four tissue types have been plotted against the five stages of growth. This enables changes in elemental concentration in the lamina to be examined directly as a function of stage of growth (time).

The sodium values show a progressive decrease during the early phases of growth but rise again at the old stage. The magnesium concentration increases to the senescent stages before falling at the final old stage. The levels of aluminium, phosphorus, sulphur and chlorine all decrease as growth proceeds. The silicon values appear to remain constant although they are close to what is considered to be the minimum-detec- tion limit. As the juvenile leaf expands by an increase in growth and vacuolation to form the mature leaf, there is an increase in the uptake of potassium. During the subsequent ripening, and senescent stage, the potassium levels decrease. There is an increase in the levels of calcium in the latter stages of growth. Although a number of elements at particular phases of growth are below the minimum-detection limit, it will be necessary to examine these levels more closely to see if there are local concentrations in a particular tissue type.

A series of coefficient of correlation matrices shows that a positive correlation exists between a number of the elements and that these relationships persist during different stages of growth. These relationships are summarized in Table 5. There is a positive correlation between $K$ \& $P$ throughout the five stages of growth, with the relationship being more positive in the early development of the leaf. A similar relationship is seen between $P \& \mathbf{M g}$, but in this case the relationship is more positive during the final stages of growth. The relationship between $\mathrm{K} \& \mathrm{Mg}$ is positive during the early stages of growth, but becomes less positive as the leaf ages. Other positive correlations can be seen, i.e. between $\mathrm{S} \& \mathrm{P}, \mathrm{Ca} \& \mathrm{Mg}$ and $\mathrm{Ca} \& \mathrm{~S}$ during the early stages of growth.

The second set of data analysis is given in Fig. 2 which shows variations in elemental concentrations both as a function of tissue type as indicated by the four different graph lines and stage of growth as indicated by five points along the horizontal axis. For the sake of clarity, standard errors of the mean have not been included on the figures. However in order to have some idea of the significance of these results as they relate, one to each other, it should be accepted that the standard error of the mean is generally within $5 \%$ of the mean value.

The levels for sodium in the palisade tissue remain constant throughout the five stages of growth. This is in marked contrast to the level of sodium in the other tis- 
Figure 2.

Elemental concentrations In cells from each of the four major tissue types of leaves of Nicotiana tabacum as a function of the stage of growth. Values are given as $\mathrm{mol} \mathrm{m}^{-3}$ fresh weight.
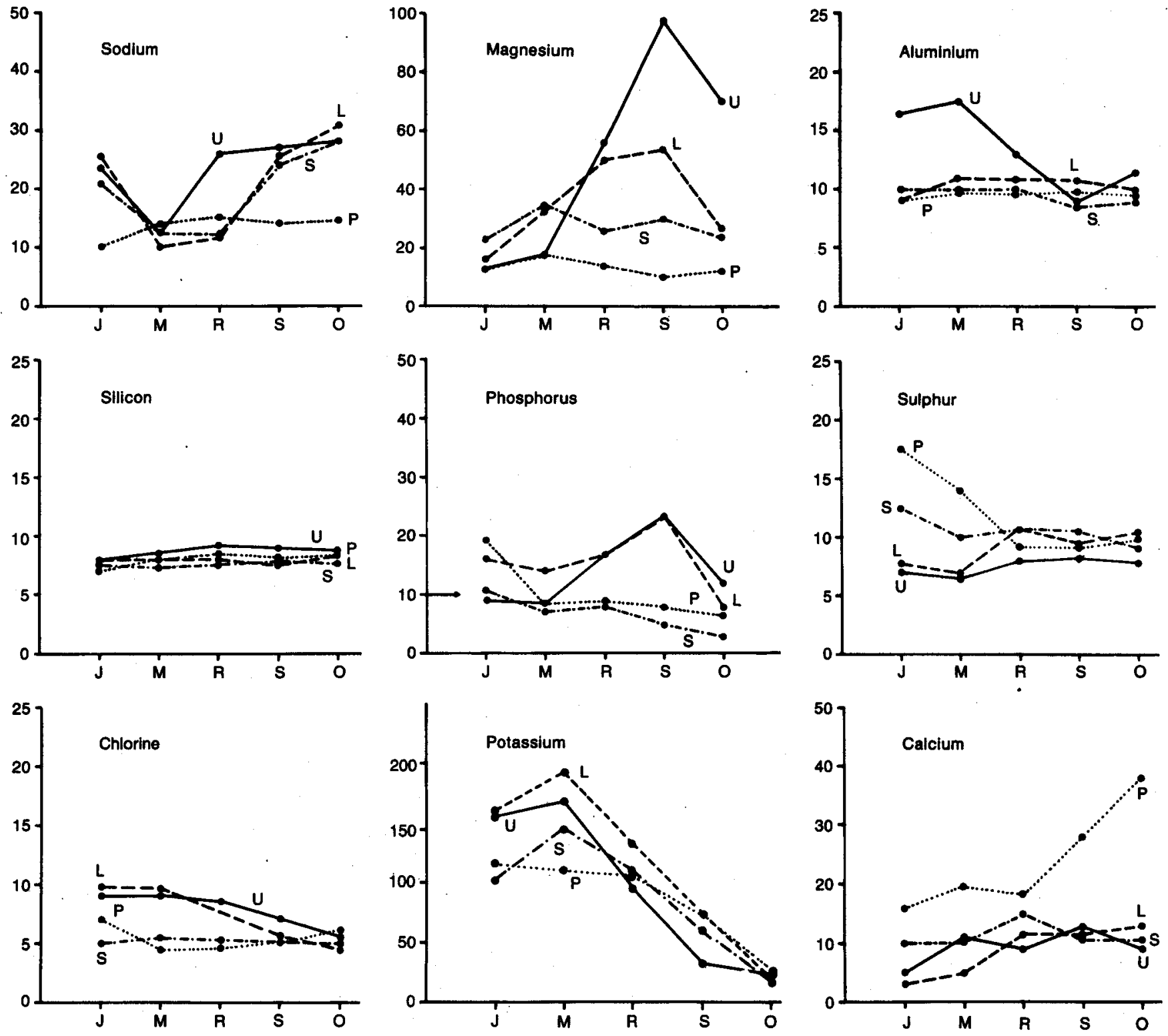

Upper epidermis (U)

Spongy mesophyll (S)

Palisade (P) :

Lower epidermis (L):

$J:$ Juvenile $(n=65)$,
$M:$ Mature $(n=67)$,
$R:$ Ripe $(n=64)$,
S: Senescent $(n=62)$,
: : Old $(n=64)$. 
sues where there are significantly higher levels at the early and late stages. In contrast to the values for sodium, the figures for magnesium show considerable variation, with the levels in the two photosynthetic tissues being generally lower than that seen in the two epidermal layers.

With the exception of the anomalously high value for aluminium in the upper epidermis in early stages of growth, the levels for this element and silicon are all below the minimum-detection limit. The levels for phosphorus in the photosynthetic tissue gradually fall as the leaf matures and ages. In contrast, the levels in the upper and lower epidermis show considerable fluctuation. The sulphur levels are generally low in the different tissues of the leaf. The levels in the photosynthetic layers decrease with age, and the levels in the two epidermal layers show a small increase. The chlorine levels show little variation between the different tissue types and are all below the minimum-detection limit.

Of all the elements measured in the leaf tissue, potassium is present in the highest amount and shows the most significant changes. With the exception of the palisade tissue; the potassium levels increase as the leaf matures and then decrease as the leaf ripens and ages. By the old stage, the level of potassium in all tissues is approx, $25 \mathrm{~mol} \mathrm{~m}^{-3}$ which, depending on the tissue type, represents a four to eightfold decrease from the values found at the mature stage of growth. The calcium levels in the two epidermal layers and the spongy mesophyll show little significant variation during growth. The calcium levels in the palisade are constant at $20 \mathrm{~mol} \mathrm{~m}^{-3}$ during the first three phases of growth and double during the senescent and old phases.

An examination of the results presented so far indicates that the elemental concentrations in the photosynthetic tissues (palisade and spongy mesophyll) are usually different from those found in the two epidermal layers. It would seem appropriate to reanalyse the data on this premise. With a few exceptions, the low levels of aluminium, silicon and chlorine indicate that they need not be considered any further.

In the next of these further computations, the four cell types of the leaf are combined into two tissue types, photosynthetic and non-photosynthetic, and the changes in the concentration of six elements, $\mathrm{Na}, \mathrm{Mg}$, $\mathrm{P}, \mathrm{S}, \mathrm{K}$ and $\mathrm{Ca}$, are plotted as a function of the leaf age. This data is shown in Fig. 3.

The values for sodium show differences between the two tissue types at the juvenile and old stages of growth, although the concentrations show little significant variation at the mature, ripe and senescent phases. At the juvenile and mature stages, the magnesium values appear identical in the two tissue types. As leaf ripening proceeds, the magnesium concentration in the photosynthetic tissues falls back to the level measured at the juvenile stage of growth, and remains constant during further leaf senescence. In contrast, the magnesium concentration in the epidermal tissue is doubled by the ripe stage of growth, shows a small increase by the senescent stage and decreases at the old stage. There is a progressive loss of phosphorus from the photosynthetic tissues as the leaf ages. The levels in the epidermal layers are more or less constant during the first three stages of growth, show a small increase by the senescent stage, and fall back at the final growth stage. The values for sulphur reverse this general trend of higher elemental concentrations in the epidermal tissue than in the photosynthetic tissues. The levels in the epidermal layers are low, and whereas the values for sulphur in the photosynthetic tissues are high in the juvenile and mature stages, as the leaf ripens and ages further, so the values fall.

The potassium concentrations in the two tissue layers show considerable differences in the early phases of growth, but it is of interest to note that they appear to be identical in the later stages. From the maximum concentration at maturity there is an eightfold decrease in potassium in the epidermal cells and a fivefold decrease in the level in the photosynthetic tissues by the old stage of growth. The calcium concentrations, although low, are significantly different between the two tissue types. Throughout the five stages of growth, the levels of calcium are twice as high in the photosynthetic tissues than in the combined epidermal layers. This is in contrast to the levels of magnesium, which are low in the photosynthetic tissues and three times higher in the epidermal layers.

Coefficients of correlation have been calculated between the different elements at each of the five stages of growth. Because of the large amount of data generated by a coefficient of correlation matrix, a summary of the main trends is given in Tables 6 and 7. Table 6 shows that in the photosynthetic tissues there is a positive correlation between $P \& K$ at the first four stages of growth although the actual figures show that the correlation becomes less positive as growth proceeds. Similarly there is a positive correlation between $P \& S$, $\mathrm{Mg} \& \mathrm{~K}$ and $\mathrm{K} \& \mathrm{~S}$ during the early stages of growth. The positive correlation between $\mathrm{P} \& \mathrm{Mg}$ is only seen in the final old stage of growth.

In many respects the pattern of correlation is reversed in the non-photosynthetic tissues (Table 7). There is a progressively more positive correlation between magnesium \& phosphorus throughout all five stages of growth, the $\mathrm{Mg} \& \mathrm{~K}$ and $\mathrm{P} \& \mathrm{~K}$ correlations are only evident at the early stages of growth while the correlation between $P \& S$ and $K \& S$ is the same as in the photosynthetic tissue.

\section{DISCUSSION}

There is a large amount of literature on the redistribution and fluctuation of inorganic elements in tobacco as a function of age, physiological condition and species [see Akehurst (13) as a general introduction to this work]. These earlier studies, unlike the work reported here, have all been carried out on the whole leaf with 
Table 5.

Summary of the correlation-coefficlent matrices made on nine elements from the combined values for the four tissue types at flve stages of growth. Only values at a $99 \%$ confidence limit are included.

\begin{tabular}{|c|c|c|c|c|c|c|c|}
\hline \multirow{2}{*}{$\begin{array}{l}\text { Stages of growth } \\
\text { Juvenile }\end{array}$} & \multicolumn{7}{|c|}{ Positive correlation } \\
\hline & P \& Mg & $P \& K$ & $P \& S$ & $M g \& K$ & $K \& S$ & - & - \\
\hline Mature & $P \& M g$ & $P \& K$. & $P \& S$ & $M g \& K$ & $K \& S$ & $\mathrm{Ca} \& \mathrm{Mg}$ & $\mathrm{Ca} \& \mathrm{~S}$ \\
\hline Ripe & P \& Mg & $P \& K$ & - & $M g \& K$ & - & - & - \\
\hline Senescent & P \& Mg & $P \& K$ & - & - & - & - & - \\
\hline Old & $P \& M g$ & $P \& K$ & - & - & - & - & - \\
\hline
\end{tabular}

Table 6.

Summary of the correlation-coefficlent matrices between six elements present In the photosynthetic tissues of tobacco leaves at five stages of growth.

Only positive correlations at a $99 \%$ significance level are included.

\begin{tabular}{l|cccccc}
\hline Stages of growth & \multicolumn{7}{c}{ Positive correlation } \\
\hline Juvenile & - & P \& K & P \& S & Mg \& K & K \& S & - \\
Mature & - & P \& K & P \& S & Mg \& K & $K$ \& S & Ca \& S \\
Ripe & - & P \& K & P \& S & Mg \& K & - & - \\
Senescent & - & P \& K & - & - & - & - \\
Old & $P \& M g$ & $P \& K$ & - & - & - & - \\
\hline
\end{tabular}

Table 7.

Summary of the correlation-coefficient matrices between six elements present in the non-photosynthetic (epldermal) tissues of tobacco leaves at flve stages of growth. Only positive correlations at a $\mathbf{9 9 \%}$ significance level are included.

\begin{tabular}{l|ccccccc}
\hline Stages of growth & \multicolumn{7}{|c}{ Positive correlation } \\
\hline Juvenile & Mg \& S & P \& Mg & P \& K & P \& S & Mg \& K & K \& S & - \\
Mature & - & P \& Mg & P \& K & P \& S & - & K \& S & Ca \& S \\
Ripe & - & P \& Mg & - & - & - & - & Ca \& S \\
Senescent & $M g \& S$ & $P \& ~ M g$ & - & - & - & - & Ca \& S \\
Old & $M g \& S$ & P \& Mg & - & - & - & - & Ca \& S \\
\hline
\end{tabular}


no regard for any differences which might occur at the cell and tissue level. The results reported here are only representative of green-house grown cv. Coker 319 Bright tobacco and are likely to differ from field-grown plants and with other varieties of tobacco. It has not been possible to apply the unique type of cellular analysis used in this study to other tobacco varieties. However, the elemental concentrations in whole leaf and their variations with age which are reported here, are similar to the general effects seen in bright tobaccos analysed by other means $(13,14)$.

The changes in local elemental concentration which have been measured in green leaves of Bright tobacco at five stages of growth are probably best understood in relation to the two major phases in the life cycle of the plant: growth and senescence. The juvenile and mature leaves are representative of the growth phase which in a monocarpic plant is characterized by a net import of organic materials and some ions from older leaves together with water and minerals from the roots. The ripe, senescent and old leaves are associated with the senescence syndrome of plants which is characterized by a net export of soluble organic and inorganic materials from the dying leaves to other parts of the plant. Senescence is an important development process which contributes to a decline in productivity of many economically important plants. In the case of monocarpic plants such as tobacco, this decline in productive capacity of the leaves occurs at about the same time as the formation of fruits and seeds. The changes which have been measured for the major minerals in the tobacco leaf are similar to the changes measured in the whole leaves of other maturing and senescing plants. This general phenomenon of senescence which includes biochemical and ultrastructural changes in relation to changes in the levels of plant-growth substances are well documented in the literature $(15,16,17)$ and will not be discussed here.

It is difficult to relate the earlier work on senescence to the experiments described in this present paper. Much of the classical work on leaf senescence was carried out either on detached leaves or on leaf discs. This approach, while arguably a more controlled way of studying senescence because the influence of metabolic and hormonal changes in other parts of the plant may be discounted, may be far removed from the biochemical and physiological processes which occur in the whole plant. The growth and senescence of an individual leaf is influenced by what goes on in other parts of the plant. The leaf is both a source and sink for nutrients and as this present study shows, the mobility of minerals varies depending on the tissue and the stage of development. It would appear that in monocarpic species, the plant body may not be able to take up enough minerals for reproductive growth and relies on retrieval of elements from older tissues in order to complete the reproductive cycle. There have been very few studies on the redistribution of minerals in relation to senescence; such studies are usually only concerned with fruit formation. It has been shown (18) that in soybean,
$90 \%$ of the $\mathrm{P}$ and $\mathrm{K}$, but less than $20 \%$ of $\mathrm{Ca}$ and $\mathrm{Na}$ is redistributed from the leaves to the fruit. This redistribution still takes place when there is a plentiful supply in the soil which would suggest that movement of minerals from the leaves is a consequence of senescence rather than a cause.

As the young leaf unfolds so the rate of import of organic material increases and reaches a maximum when the leaf is approximately $20 \%$ to $30 \%$ full size (19). The importation ceases when the leaf is approximately $50 \%$ to $75 \%$ full size. The juvenile leaves used in this study correspond to this phase of growth. In plants generally, although there is a substantial export of organic material from the older leaves to younger leaves, the young leaves are also beginning to photosynthesize. It can be shown that export of locally fixed carbon from young leaves begins at about the time all division ceases in the palisade cells which corresponds to a plant where the leaf is between a third and half its full size (20).

Because the pool of inorganic ions within the young leaf is very limited, the mineral ions needed during this active phase of cell division and expansion are derived from the roots (via the xylem) and the older leaves (via the phloem). The exact proportion depends on the nutritional status and the relative mobility of the different ions in the phloem. Plants grown in low nitrogen, derived $70 \%$ of their nitrogen from older leaves and plants grown in high nitrogen showed no nitrogen distribution from older leaves until late into senescence (19). The growth medium used in this present study was not limiting so that during the early stages of growth it is likely that a substantial proportion of the minerals were derived from the root. At these early stages of growth, the six older leaves in the lower stalk position are in the middle stages of growth and while it is likely that they are exporting organic material, they are not considered to be a major source of minerals for the younger leaves. In addition, it is likely that the juvenile leaves may have an enhanced requirement for minerals, as it has been reported (21) that leaves of plants grown in high nitrogen have a greater number of cells with more rapid cell elongation, and increased leaf length. Mid-stalk tobacco leaves at the juvenile stage of growth are metabolically active. This activity is reflected in the distribution and local concentration of mineral elements in the four main tissues of the leaf.

A small amount of sodium is needed for enzyme activation and any excess is probably localized in the vacuoles of the spongy mesophyll and the epidermal layers. The gradual increase in sodium concentration in the spongy mesophyll and the two epidermal layers in the later stages of growth may well be associated with the lower mobility of this element in the phloem, and a diminished need of the cation in other parts of the plant.

Magnesium has several roles in cell metabolism although these requirements are satisfied with very low (approx. $5 \mathrm{mmol} \mathrm{m}^{-3}$ ) concentrations (22), well below the sensitivity of the X-ray analytical system. Much 
Figure 3.

Elemental concentrations in cells from the photosynthetic tissues (palisade and mesophyll) and non-photosynthetic tissues (upper and lower epidermis) from leaves of Nicotian tabacum as a function of the stage of growth. Values are given as $\mathrm{mol} \mathrm{m}^{-3}$ fresh weight ( \pm standard error of the mean).
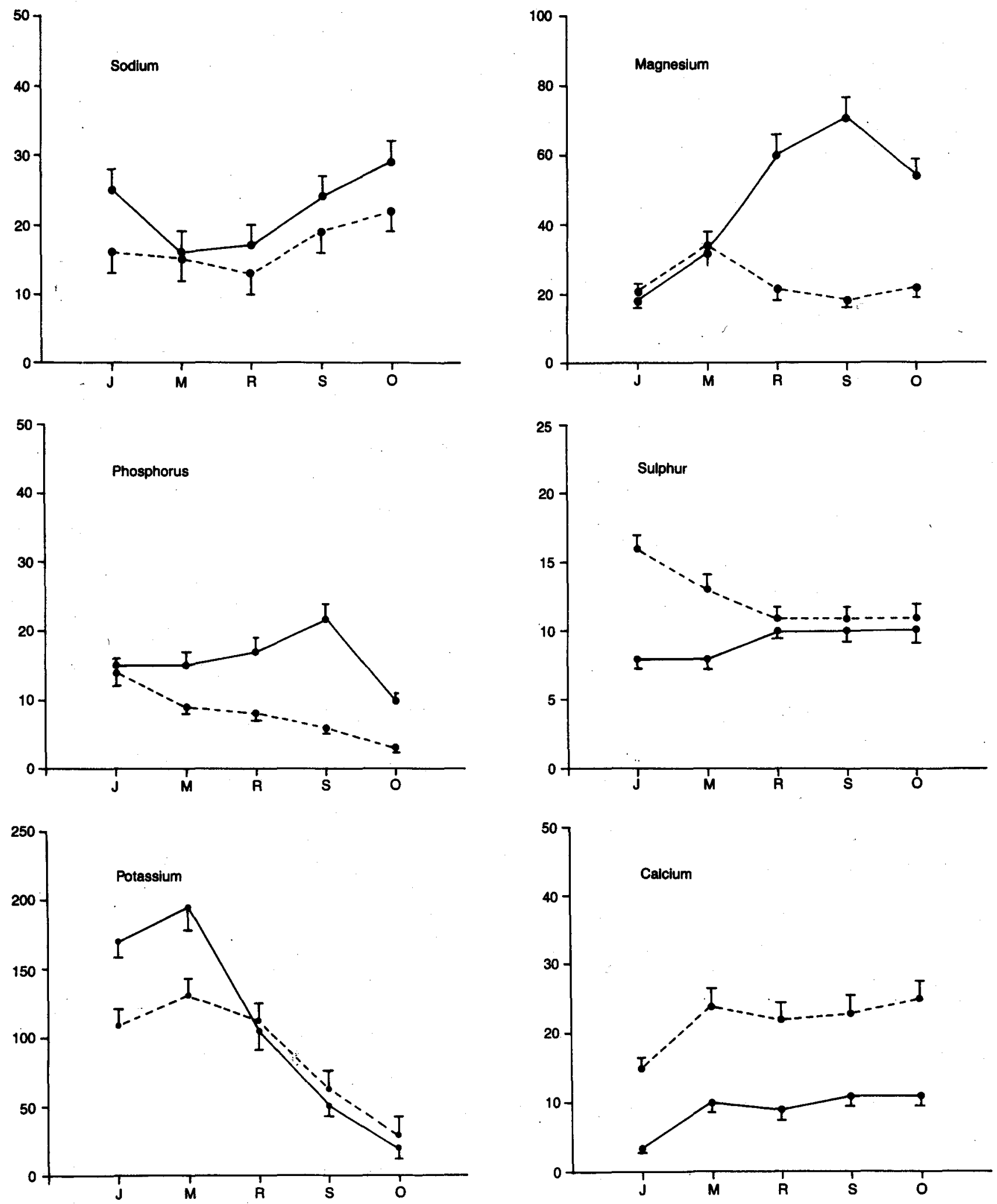
higher concentrations of magnesium are known to be present in photosynthetic cells where up to $15 \%$ to $20 \%$ of the cation is associated with chlorophyll. Magnesium is also associated with the pectic acids of the middle lamella of the cell wall and some is sequestered in other tissues of the plant as phytin, the hexaphosphoric esters of inositol. In the early stages of growth, the bulk of the element is present in a diffusible form associated with the organic acids. The juvenile tobacco leaves are only a quarter full size and because cell expansion is primarily a consequence of vacuolation, there is a smaller requirement for magnesium to act as a counter cation for the vacuolar organic acids. As the tobacco leaves enlarge and mature, so the concentration of the cation increases. It is of interest to note that in the early phases of growth there is a positive correlation between the concentrations of magnesium and potassium, the principal counter cation of plant tissue. This relationship does not exist in the later phases of growth.

Work on barley (4) has shown that magnesium is osmotically active in the early stages of growth, and work on soybean (23) and tomato (24) showed that there was an increase in the magnesium content as the leaf matured. This same general phenomenon is seen in this present study on tobacco, although as the mature leaf ripens and senesces, the concentration of magnesium in the photosynthetic tissue decreases while there is a progressive increase in the two epidermal layers. It is generally assumed that magnesium is phloem mobile although the cited evidence is conflicting (25). As photosynthesis decreases in the palisade and mesophyll tissue, the photosynthesis apparatus is progressively disassembled, the chlorophyll content decreases and the excess magnesium is lost from these cells. Concomitant with these changes, there is an increase in magnesium levels in the two epidermal layers, a feature which is also shared by the levels of phosphorus. At the final old stage, the magnesium concentration begins to drop away as the bound magnesium compounds are solubilized.

Phosphorus is usually taken up by the plant as phosphate and is quickly esterified. Phosphorus is needed by the plant for energy conversions and transfer of metabolites, particularly in the movement of photosynthetic products such as hexose esters out of the leaves to other parts of the plant (26).

This general phenomenon is seen here except that there is a distinct partition between what happens in the photosynthetic tissues and in the non-photosynthetic tissues. There is a gradual decrease in the phosphorus level in the palisade and mesophyll cells as photosynthesis decreases and the leaf ages. The progressive increase in phosphorus in the epidermal layers is associated with an increase in the level of magnesium. As noted earlier (Tables 5, 6 and 7) although there is a positive correlation between the concentrations of phosphorus and magnesium during most phases of growth, this relationship is less positive in the early stages of growth of the photosynthetic tissue and more positive in the late stages of growth in the non-photosynthetic tissue. The accumulation of phosphorus and magnesium in the epidermal layers is either a consequence of the need to sequester excess magnesium or simply that in the early stages of senescence this normally highly mobile element is in a form which cannot be removed fast enough from the leaf tissues. By the old stage the phosphorus is at its lowest level in all tissues of the leaf although the magnesium remains high in the upper epidermis. Sulphur is not considered to be a very mobile element and little is redistributed in the plant. The younger leaf tissues are dependent on sulphate taken up by the plant roots.

Potassium is the major cation of plant cells and is generally present at a concentration of between 100 and $250 \mathrm{~mol} \mathrm{~m}^{-3}$. Although most of the potassium is taken up from the soil during the vegetative stages of growth, there is considerable mobility of the element within the plant. The principal role of this element is in maintaining cell turgor and in osmoregulation where it forms the counter cation to organic acids, principally malic acid, in the vacuole. Not all the potassium is associated with organic acids, some may be associated with nitrate. In roots of onion, some of the potassium may be associated with anionic charge groups such as sulphate (2). This important role in maintaining cell turgor has a dynamic manifestation in cell expansion, a characteristic feature of cells during the early stages of leaf growth and development. This role is seen in the work presented here, for the highest concentrations of potassium are found in the two epidermal layers and the spongy mesophyll at the mature stage of growth at which stage the leaves have reached their full size. It is interesting to note that the palisade cells, the principal photosynthetic tissue, have a slightly higher concentration of potassium at the early juvenile stage which would suggest a somewhat earlier maximum expansion of this tissue in the leaf. The level of potassium in the palisade cells remains more or less constant throughout the early stages of growth and ripening, and suggests that the element also has roles other than maintaining cell turgor.

As the leaf ripens, more and more potassium is lost from all four tissue types and it is remarkable that the approximate threefold decrease in potassium between the mature and senescent stages of growth is not accompanied by more visible changes in cell turgor. Presumably, other cell components such as carbohydrates and organic constituents maintain cell and tissue turgor. This progressive loss of potassium is in agreement with the earlier findings that a substantial amount of the leaf potassium will move out of the tissue during senescence. Studies with barley (27) showed that potassium moved from old tissues to new, similar findings were reported for cucumber (20) and beetroot (28). These earlier studies and the present findings demonstrate that potassium is one of the most phloem-mobile elements and that unlike other elements, this mobility does not appear to be diminished with age.

The variations in calcium concentrations are best ex- 
plained in terms of oxalic-acid accumulation in the vacuoles in the early stages of growth which in turn may be related to photorespiration, osmoregulation and maintenance of $\mathrm{pH}$, and the general phenomenon of senescence process in the later stages of growth. The lower levels of calcium in the juvenile leaves are to be expected because cell-wall deposition and expansion is not complete and photosynthesis has not reached the maximum level. However, the higher levels in the photosynthetic tissue and in particular in the palisade cells are probably related to the formation of oxalic acid. In a comprehensive study of organic acid metabolism in tobacco (29) it has been shown that there is a slightly increased amount of oxalic acid at the younger stages of growth. Oxalate is generally considered to be an end product of metabolism (30) and it is unlikely that any calcium present in calcium-oxalate crystals would be returned to active metabolic processes. In some tobacco varieties, the high amounts of oxalic acid may absorb most of the calcium causing the plants to exhibit calcium-deficiency symptoms. In the juvenile leaves of this present study, any oxalate would probably be bound to the more abundant potassium ion rather than calcium, as the latter cation is present only in low concentration and most certainly associated with the developing cell walls.

As the tobacco leaf expands and matures, the calcium level is nearly doubled in the whole tissue, with a slightly greater increase in the photosynthetic tissue. This increase is considered to be related to two events which are going on in the leaves at this stage of growth. It has been shown that plants growing on nitrate as a nitrogen source, produce an excess of hydroxyl ions which cause the $\mathrm{pH}$ of the sap to rise (31). Plants respond to this $\mathrm{pH}$ change by producing organic acids such as oxalate which would neutralize the rise in $\mathrm{pH}$. Soluble organic-acid salts such as potassium malate or oxalate would upset the ionic balance, but precipitation of oxalate as the insoluble calcium salt would restore the ionic balance. In differentiated cells this oxalate would be stored in the vacuole.

An additional source of oxalic acid would be photorespiration. Tobacco is a $\mathrm{C}_{3}$ plant and it is known that in high light there is an increased production of oxalic acid. The glycolate and glyoxylate produced as a result of photorespiration - a feature of $\mathrm{C}_{3}$ photosynthesis at high light levels - are oxidized to oxalate by glyoxylate oxidase which is known to be present in high amounts in tobacco plant (32). The oxalate would be precipitated as the calcium salt to avoid upsetting the ionic balance. It is worth noting that in this study on tobacco, where the plants were grown at high light levels, palisade cells, the principal photosynthetic tissue, have the highest amounts of calcium.

These higher levels of calcium are maintained during the ripe, senescent and old stages of growth, but not due to nitrate assimilation or photorespiration. It is well known that calcium is phloem immobile and that once it has accumulated in the leaf it shows very little decrease with time. This factor would favour the main- tenance of higher levels of leaf calcium, and there is some evidence that these higher calcium levels may well presage and even stimulate the process of leaf senescence (33). The presence of oxalic acid and inorganic phosphorus would tend to sequester calcium from the cytosol and reduce the cytosolic level to the point where membranes lose their functionality resulting in a leakage of cellular components and a disorganization of metabolic processes. The continued and progressive growth of calcium-oxalate crystals would also sequester calcium from the remaining pectic middle lamella of cell walls, which in turn would be progressively weakened. Many of the symptoms and processes of senescence can be reversed by adding soluble calcium salts to the tissues concerned (33). Although the calcium levels appear higher in the photosynthetic tissues, this increased level is due primarily to the substantially higher levels in the palisade cells. The calcium levels in this tissue show spectacular increases during the later phases of growth and this can be related to the finding that most of the calcium-oxalate crystals are found associated with this cell type.

All the previous work which has been carried out on the relative phloem mobility of different elements has been carried out on whole leaves. One of the findings this present study has shown is that the mobility of an element is dependent on the tissue in which it is located as well as the age of the tissue. The photosynthetic tissues appear to lose elements more rapidly than the epidermal layers, possibly because they are more intimately connected with the long-distance transporting system of the plants. It is also possible that the epidermal tissues in senescing leaves retain their metabolic capacity and act to remove excessive cations from the cytosol of the photosynthetic tissues.

\section{REFERENCES}

1. Dale, J. E., F. L. Milthorpe (eds.): The growth and functioning of leaves; Cambridge University Press, Cambridge, 1983.

2. Cameron, A. L., K. E. Hunter and N. K. R. Smith: The subcellular concentration of ions and elements in cryosections of onion root meristem; J. Cell Sci 72 (1984) 295-306.

3. McCully, M. E., M. J. Canny and R. F. M. van Steveninck: Accumulation of potassium by differentiating metaxylem elements of maize roots; Physiol. Plant. 69 (1987) 73-80.

4. Leigh, R. A., M. Chater, R. Storey and A. E. Johnstone: Accumulation and sub-cellular distribution of cations in relation to the growth of $\mathrm{K}^{+}$deficient barley; Plant, Cell and Environ. 9(1986) 595-604.

5. Echlin, P., and S. E. Taylor: The preparation and $\mathrm{X}$-ray microanalysis of bulk frozen hydrated vacu- 
olate plant tissue; J. Microsc. (Oxf.) 141 (1986) 329-348.

6. Pawley, J. B., and J. T. Norton: A chamber attached to the SEM for fracturing and coating frozen biological specimens; J. Microsc. (Oxf.) 112 (1978) 160 -182.

7. Statham, P. J., and J. B. Pawley: A new method of particle X-ray microanalysis based on peak to background measurements; Scanning Electron Microsc. $1978(\mathrm{I}), 469-478$.

8. Statham, P. J.: Measurement and use of peak to background ratios in X-ray microanalysis; Microchim. Acta Suppl. 8 (1979) 229-238.

9. Ronnhult, T., B. Brox and G. Fritze: The influence of surface topography on the X-ray intensity in the electron probe analysis (EDS/WDS); Scanning 9 (1987) 81-87.

10. Pearce, R. S., and A. Beckett: Cell shapes in leaves of drought-stressed barley examined by low temperature scanning electron microscopy; Ann. Bot. (Lond.) 59 (1987) 191-195.

11. Echlin, P.: Artefacts in the X-ray microanalysis of frozen hydrated biological samples; Proc. 45th Annu. Meeting of the Electron Microscope Society of America, ed. G. W. Bailey, San Francisco Press, San Francisco, Calif., pp. 658-659, 1988.

12. Willard, H. H., L. Ol. Merritt, J. A. Dean and F. A. Settle: Instrumental methods of analysis, 7th ed., Wadsworth Publishing Company, Belmont, California, 1988.

13. Akehurst, B. C.: 'Tobacco, 2nd ed., Longman, London and New York, 1981.

14. Tso, T. C.: Micro- and secondary elements in tobacco; Bot. Bull. Acad. Sin. (Taipei) 7 (1966) 28-63.

15. Thimann, K. V. (ed.): Senescence in plants; CRC Press, Boca Raton, Fla., 1981.

16. Woolhouse, H.W., and G. I. Jenkins: Physiological responses, metabolic changes and regulation during leaf senescence; in The growth and functioning of leaves, ed. J. E. Dale and F. L. Milthorpe, Ch. 15, Camb. Univ. Press, Cambridge, 1983.

17. Leshem, Y. Y., A. J. Halevy and C. Frankel: Processes of control of plant senescence; Elsevier, Amsterdam, 1986.

18. Nooden, L. D.: Senescence in the whole plant; in Senescence in plants, ed. K. V. Thimann, Ch. 10, CRC Press, Boca Raton, Fla, 1980.

19. Dale, J. E., and F. L. Milthorpe: General features of the production and growth of leaves; in The growth and functioning of leaves, ed. J. E. Dale and F. L. Milthorpe, Ch. 6, Camb. Univ. Press, Cambridge, 1983.
20. Ho, L. C., R. G. Hurd, L. J. Ludwig, A. F. Shaw, J. M. H. Thornley and A. C. Withers: Changes in photosynthesis, carbon budget and mineral content during the growth of the first leaf of cucumber; Ann. Bot. (Lond.) 54 (1984) 87-101.

21. Terry, N., N. J. Waldron and S. E. Taylor: Environmental influences on leaf expansion; in The grow th and functioning of leaves, ed. J. E. Dale and F. L. Milthorpe, Ch. 7, Camb. Univ. Press, Cambridge, 1983.

22. Wynn-Jones, R. G., C. J. Brady and J. Spiers: Ionic and osmotic relations in plant cells; in Recent advances in the biochemistry of cereals, ed. D. L. Laidman and R. G. Wynn-Jones, Academic Press, ' London, 1979.

23. Derman, B. D., D. C. Rupp and L. D. Nooden: Mineral distribution in relation to fruit development and monocarpic senescence in Anoka soybeans; Am. J. Bot. 65 (1978) 205-213.

24. Ho, L. C., and A. F. Shaw: Net accumulation of minerals and water and the carbon budget of expanding leaves of tomato; Ann. Bot. (Lond.) 43 (1979) 45-54.

25. Williams, R. F.: Redistribution of mineral elements during development; Annu. Rev. Plant Physiol, 6 (1955) 25-42.

26. Macnicol, P. K., R. E. Young and J. B. Biale: Metabolic regulation in the senescing tobacco leaf; Plant Physiol. (Bethesda) 51 (1973) 793-797.

27. Greenway, H., and M. G. Pitman: Potassium retranslocation in seedlings of Hordeum vulgaris; Aust. J. Biol. Sci. 18 (1965) 235-247.

28. Graham, R. D., and A. Ulrich: Re-translocation of potassium in Beta vulgaris L. under conditions of low sodium supply; Aust. J. Plant Physiol. 1 (1974) 387-396.

29. Vickery, H. B.: Chemical investigations of the tobacco plant, XI. Composition of the green leaf in relation to position on the stalk; Conn. Agric. Exp. Stn. Bull. (New Haven) 640 (1976) 221-236.

30. Franceschi, V. R., and H. T. Horner: Calcium oxalate crystals in plants; Bot. Rev. 46 (1980) 361427.

31. Raven, J. A., and F. A. Smith: Nitrogen assimilation and transport in vascular land plants in relation to intracellular $\mathrm{pH}$ regulation; New Phytol. 76 (1976) 415-431.

32. Kelly, G. J., E. Latzko and M. Gibbs: Regulatory aspects of photosynthetic carbon metabolism; Annu. Rev. Plant Physiol. 27 (1976) 181-205.

33. Ferguson, I. B.: Calcium in plant senescence and ripening; Plant, Cell and Environ. 7 (1984) 477489. 


\section{Acknowledgements}

All the experimental work associated with this study was carried out while the author was a Visiting Scientist at the Philip Morris Research Center, Richmond, Virginia. The author is grateful to the Directors of the Research Center for including bim in on this continuing programme and for the interest and support of Dr. Bill Kwhn, Dr. Jerry Whidby. and Mr. Cliff Lilly. Much of the experimental work was carried out in association with Ms Edie Taylor and the author is grateful for ber belp. Ms Vicky Baliga and Ms Betty Handy assisted with the chemical analysis of the ripe tobacco leaves, and Mr. George West planted and maintained the many plants associated with this study. Thanks are also due to Dr. Danny Ennis for providing the statistical background for setting up and analysing the experiment.

Author's address:

Department of Botany,

Botany Scbool

University of Cambridge,

Downing Street,

Cambridge, CB2 3EA, England. 